\title{
PROSTATE VAPORIZATION BY DIODE LASER FOR PATIENTS WITH BENIGN PROSTATIC ENLARGEMENT
}

\author{
FALAH MAHDI ALI, AHMED ALI OBAID*
}

Department of Surgery, College of Medicine, University of Al -Qadisiyah, Diwaniyah, Iraq. Email: ahmed.a.obaid@qu.edu.iq

Received: 11 September 2018, Revised and Accepted: 20 October 2018

\begin{abstract}
Objectives: The objectives of this study were to study the efficacy of diode laser prostatectomy in patients infected with benign prostatic enlargement.

Methods: A total of 62 men were included in our prospective clinical study from August 2017 to January 2018 . The size of their prostates (ml) was ranged from 38 to 65 , digital rectal examination for all patients was revealed the features of benign prostatic enlargement, prostate-specific antigen was ranged from 0.3 to $14 \mathrm{ng} / \mathrm{ml}$, underwent laser prostatectomy (Diode laser).

Results: The study included 62 men with $67.82 \pm 7.57$ years. After the operation, the median maximum flow rate (Qmax) was increased $11-22$ ml/s and the increment was highly significant $(\mathrm{p}<0.001)$, and median international prostate symptom score was highly significantly reduced from 19 to 10 ( $\mathrm{p}<0.001$ ). In addition, median residual volume was highly significantly reduced from 169.5 to $77 \mathrm{ml}(\mathrm{p}<0.001$ ). Mean duration of operation was $67.82 \pm 7.57 \mathrm{~min}$. The duration of catheterization with a mean of $1.16 \pm 0.45$ days. Most patients required only 1 day of hospital stay postoperatively. No one developed post-operative bleeding, erectile dysfunction was reported in a single patient (1.6\%), urinary incontinence in one patient (1.6\%), and urinary tract infection was the most frequent post-operative complication being reported in $11.3 \%$.
\end{abstract}

Conclusion: Diode laser for the treatment of prostate is easily applicable, cheap and provides good ablation with low morbidity.

Keywords: Benign prostatic hyperplasia, Digital rectal examination, prostate-specific antigen, International prostate symptom score.

(C) 2018 The Authors. Published by Innovare Academic Sciences Pvt Ltd. This is an open access article under the CC BY license (http://creativecommons. org/licenses/by/4. 0/) DOI: http://dx.doi.org/10.22159/ajpcr.2018.v11i12.295752

\section{INTRODUCTION}

The benign prostatic hyperplasia (BPH) is one of the important causes of dysfunction of the urinary tract in elderly males, and the prevalence increases with increasing age [1]. The treatment includes medical and surgical measures. The surgical measures have been included in patients with moderate-to-severe symptoms that do not respond to medical therapy or complicated BPH by stone, diverticulum, or repeated or recurrent infections.

Transurethral resection of the prostate (TURP) has been a standard surgical procedure for treatment of BPH for many years, but it has morbidity in the form of bleeding, retrograde ejaculation, urinary incontinence, and dilutional hyponatremia [2]. These symptoms are improved by laser, but it has significant complications in the form of prolonged irritative symptoms and urination of sloughed tissue after the operation [2,3]. Different types of laser are available (holmium [Ho], potassium titanyl phosphate [KTP], thulium, and diode laser) for the surgical treatment of $\mathrm{BPH}[4,5]$.

This development of laser begun in serious by Einstein in 1917, when projected the concept of tremendously focused light beams and stimulated emission of microwaves [6]. The short form for light amplification by the stimulated emission of radiation (LASER) was coined in 1957 by Maiman who produced the first visible light laser in the 1960s [7]. The frequent of LASER is determined by active medium, and the media may stimulate to LASER use in different waves; however, one wavelength is usually most favorable for this reason. In a search for prospective therapeutic methods for BPH that would be associated with less morbidity than TURP, the neodymium-doped yttrium aluminum garnet (Nd: YAG) LASER was introduced for LASER ablation [8]. The residual necrotic tissue caused bladder outlet obstruction and related symptoms for several weeks after treatment.
The lack of instantaneous tissue ablation combined with good hemostasis was eliminated at the time the KTP laser $(60 \mathrm{~W})$ was clinically introduced for the treatment of vaporization of hyperplastic obstructive prostate tissue $[9,10]$. Vaporization with the $532 \mathrm{~nm}$ KTP laser is broadly accepted, due to the short learning curve due to the simplicity of the technique $[11,12]$. However, effectiveness decreases as volume $(>70 \mathrm{ml})$ or prostate-specific antigen (PSA) $(>6 \mathrm{ng} / \mathrm{ml})$ increases [12]. What is more, most fibers lose $80 \%$ of power during the procedure [13].

Large glands may necessitate more than one fiber, due to the restricted lifespan, i.e., 275,000 J. As in recent times proposed alternative, diode LASER $(980 \mathrm{~nm}, 150 \mathrm{~W}$ ) offers a high degree of absorption in water and hemoglobin and it is considered to be the best in terms of hemostatic properties and rapid ablation rate; it has tissue penetration rate about $5 \mathrm{~mm}$ but is less acceptable due to post-operative dysuria, pain, and storage urinary symptoms [14].

\section{METHODS}

A total of 62 men were included in our prospective clinical study throughout 5 months, from August 2017 to January 2018 (patient consent was taken). Their ages range from 54 to 88 years, the following parameters were included for each patient: Maximal flow rates $(\mathrm{ml} / \mathrm{s})$ calculated by uroflowmetry, international prostate symptom score (IPSS), and residual volume ( $\mathrm{ml}$ ); size of their prostates $(\mathrm{ml})$ by abdominal ultrasound was ranged from 38 to 65 , digital rectal examination (DRE) for all patients was revealed features of benign prostatic enlargement, PSA was ranged from 0.3 to $14 \mathrm{ng} / \mathrm{ml}$, and underwent laser prostatectomy $(980 \mathrm{~nm}$, side-fire fiber, $150 \mathrm{~W}$, Diode laser, biolitec Germany), under spinal anesthesia preceded by prophylactic ceftriaxone antibiotic, by laser cystoscopy-21 French with normal saline irrigation. 


\section{RESULTS}

The study included 62 men with a mean age of $67.82 \pm 7.57$ years and an age range of 54-88 years. After the operation, the median maximum flow rate was increased from $11 \mathrm{ml} / \mathrm{s}$ to $22 \mathrm{ml} / \mathrm{s}$ and the increment was highly significant $(\mathrm{p}<0.001)$, and median IPSS was highly significantly reduced from 19 to $10(\mathrm{p}<0.001)$. In addition, median residual volume was highly significantly reduced from 169.5 to $77 \mathrm{ml}(\mathrm{p}<0.001)$, as shown in Table 1 and Fig. 1.

Mean duration of operation was $67.82 \pm 7.57 \mathrm{~min}$ and ranged from 44 to $80 \mathrm{~min}$. The duration of catheterization varied from 1 to 3 days with a mean of $1.16 \pm 0.45$ days. Most patients $(91.9 \%)$ required only 1 day of hospital stay postoperatively, three of them (4.8\%) leave hospital on the same day of operation, whereas 2 of them (3.2\%) stayed for 2 days. No one developed post-operative bleeding, erectile dysfunction was reported in a single patient (1.6\%), urinary incontinence in one patient $(1.6 \%)$ and urinary tract infection was the most frequent post-operative complication being reported in 7 patients (11.3\%) as shown in Table 2.

\section{Statistical analysis}

Data were analyzed using Statistical Package for the Social Sciences (SPSS) version 22 and Microsoft Office Excel 2010. Numeric variables were tested for normality distribution using Kolmogorov-Smirnov test and presented as the median and interquartile range. $p \leq 0.05$ was considered to be statistically significant. For the purpose of comparison, Wilcoxon Sign was used.

\section{DISCUSSION}

The treatment of BPH is done by medical and surgical options. The medical treatment is informed of $\alpha$-blockers and 5 - $\alpha$-reductase inhibitors. The surgical treatment includes open surgery, TURP, and other minimally invasive procedures. Open surgical removal has been used when medical therapy is failed or there is complicated BPH by stone, diverticulum, or repeated infections. Open surgery is aggressive and followed by many complications (wound, pain, bleeding, and erectile dysfunction) but can be done for the large-sized prostate. TURP is considered the gold standard surgical option for adenoma $<60 \mathrm{ml}$ because of better outcome regarding Qmax, IPSS, and postvoid residual (PVR), but it has mortality $0.3 \%$ and morbidity $19 \%$ (TUR syndrome, blood transfusion due to bleeding - $20 \mathrm{~g} / \mathrm{min}$ [15], and erectile dysfunction - 15\%) [16]. To decrease the complications of TURP, the LASER developed to resolve some problems. Many types of laser have been used to treat BPH. Nd:YAG LASER (1064 nm) has deep coagulation ability but poor absorption and poor vaporization leading the larger expelling of necrotic tissue that limit the use of Nd:YAG LASER (1064 nm) in BPH treatment [17]. Ho:YAG LASER (2140 nm) has the good absorptive ability by prostatic tissue, good vaporization, less necrotic tissue leading to good results comparable to TURP, but it has long learning curve [18]. KTP LASER $(532 \mathrm{~nm})$ has good prostatic tissue vaporization, good hemostasis, less coagulation depth leading to less expelling of necrotic tissue, and also the lack of tissue retrieval. Diode LASER (980 nm) has many advantages (small box size) [19], absorbed by hemoglobin and water, and this give rapid vaporization and hemostasis, tissue ablation shortening the operative time, cheaper than KTP or Holmium laser enucleation of the prostate but also the lack of tissue retrieval.

Diode LASER avoids complications of TURP and open surgery, and at the same times, it has many advantages (easily applicable, cheap, and good ablation ability - $10 \mathrm{~g} / \mathrm{min}$ ) and less blood loss $-0.2 \mathrm{~g} / \mathrm{min} 100$-fold less than TURP as Wendt and his colleagues said [20-22]. Many studies mentioned changes toward better results regarding urinary parameters after diode laser prostatectomy like Chen, Chiang, RusZat, and Erol et al. regarding IPSS (55-75\%), Qmax (5-14\%), and PVR (58-87\%). Our study selected 62-year-old men who have BPH sized 38-65 ml, PSA $<14 \mathrm{ng} / \mathrm{ml}$, and features of benign adenoma by DRE. Diode prostatectomy has been done for theirs. The changes in outcome have been seen regarding mean Qmax from 11 to $22 \mathrm{ml} / \mathrm{s}$, mean IPSS from 19 to 10 , and mean PVR from 169.5 to $77 \mathrm{ml}$ with $\mathrm{p}<0.001$ which is highly significant compared with other studies. The mean time of operation was $67.8 \mathrm{~min}$, comparable to

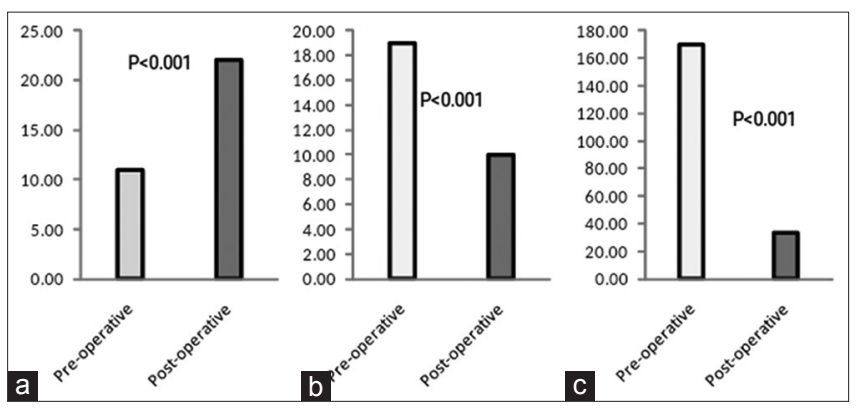

Fig. 1: Parameters before and after operation (a) Median maximum flow rate, (b) Median international prostate symptom score, (c) Median residual volume

Table 1: Parameters before and after operation

\begin{tabular}{lllllll}
\hline Characteristic & Pre-operative & & & \multicolumn{2}{c}{ Post-operative } & \multirow{2}{*}{$\mathbf{p}^{*}$} \\
\cline { 2 - 3 } & Median & IQR & & Median & IQR & \\
\hline Maximal flow rate (ml/s) & 11.00 & 6.00 & & 22.00 & 6.00 & $<0.001 \mathrm{HS}$ \\
IPSS & 19.00 & 9.25 & & 10.00 & 7.25 & $<0.001 \mathrm{HS}$ \\
Residual urine volume (ml) & 169.50 & 77.00 & 33.00 & 30.00 & $<0.001 \mathrm{HS}$ \\
\hline
\end{tabular}

IQR: Interquartile range; HS: highly significant; IPSS: International prostate symptom score; *Wilcoxon test

Table 2: Operative and post-operative events

\begin{tabular}{|c|c|}
\hline Characteristic & Value \\
\hline Duration of procedure (min); mean \pm SD (range) & $60.45 \pm 8.84(44-80)$ \\
\hline Duration of urinary catheter (day); mean $\pm S D$ (range) & $1.16 \pm 0.45(1-3)$ \\
\hline Hospital stay (day); mean \pm SD (range) & $0.98 \pm 0.28$ \\
\hline None, n (\%) & $3(4.8)$ \\
\hline For 1 day, n (\%) & $57(91.9)$ \\
\hline For 2 days, $\mathrm{n}(\%)$ & $2(3.2)$ \\
\hline Post-operative bleeding; n (\%) & $0(0)$ \\
\hline Erectile dysfunction; n (\%) & $1(1.6)$ \\
\hline Urinary incontinence; n (\%) & $1(1.6)$ \\
\hline Urinary tract infection; n (\%) & $7(11.3)$ \\
\hline
\end{tabular}


TURP or open surgery. The mean duration of the urinary catheter was 1.16 day, and this is less than TURP or open surgery. Hospital stay is 1 day, and this is good, no post-operative bleeding. Erectile dysfunction after the procedure only $1.6 \%$. Urinary tract infections are the main problem because of necrotic tissue.

No mortality, very low morbidity with good outcome compared to other LASER procedures, and TURP make this procedure more preferable in spite of the standardization of TURP.

\section{CONCLUSION}

Diode LASER for the treatment of prostate is easily applicable, cheap and provides good ablation with low blood loss.

\section{AUTHORS' CONTRIBUTIONS}

The authors contributed to all of the writing process of this article.

\section{CONFLICTS OF INTEREST}

The authors declare that there are no conflicts of interest regarding the publication of this paper.

\section{REFERENCES}

1. AUA practice Guidelines Committee. AUA guidelines on management of benign prostatic hyperplasia. Chapter 1: Diagnosis and treatment recommendations. J Urol 2003;170:530-47.

2. Lee NG, Xue H, Lerner LB. Trends and attitudes in surgical management of benign prostatic hyperplasia. Can J Urol 2012;19:6170-5

3. Gravas S, Bachmann A, Reich O, Roehrborn CG, Gilling PJ, De La Rosette J. Critical review of lasers in benign prostatic hyperplasia (BPH). BJU Int 2011;107:1030-43.

4. Einstein A. Zur Quantentheorie der Strahlung. [On the Quantum Mechanics of Radiation]. Phys Z 1917;18:121-8.

5. Al-Grawi ED, Al-Awsi GR. Expression of CDKN2A (P16/Ink4a) among colorectal cancer patients: A cohort study. J Pharm Sci Res 2018;10:5.

6. Hofstetter A, Alarcon-Hofstetter A. Treatment of prostatic tumors with interstitial thermocoagulation with neodymium-YAG. (A new treatment in minimally invasive surgery). Arch Esp Urol 1993;46:317-9.

7. Costello AJ, Bowsher WG, Bolton DM, Braslis KG, BurtJ. Laser ablation of the prostate in patients with benign prostatic hypertrophy. Br J Urol 1992;69:603-8.

8. Malek RS, Barrett DM, Kuntzman RS. High-power potassium-titanylphosphate (KTP/532) laser vaporization prostatectomy: $24 \mathrm{~h}$ later. Urology 1998;51:254-6.

9. Reich O, Bachmann A, Schneede P, Zaak D, Sulser T, Hofstetter A.
Experimental comparison of high power $(80 \mathrm{~W})$ potassium titanyl phosphate laser vaporization and transurethral resection of the prostate. J Urol 2004;171:2502-4.

10. Reich O, Bachmann A, Siebels M, Hofstetter A, Stief CG, Sulser T. High power $(80 \mathrm{~W})$ potassium-titanylphosphate laser vaporization of the prostate in 66 high risk patients. J Urol 2005;173:158-60.

11. Horasanli K, Silay MS, Altay B, Tanriverdi O, Sarica K, Miroglu C. Photoselective potassium titanyl phosphate (KTP) laser vaporization versus transurethral resection of the prostate for prostates larger than $70 \mathrm{ml}$ : A short term prospective randomized trial. Urol 2008;71:247-51.

12. Zhao Y, Liu C, Zhou G, Yu C, Zhang Y, Ouyang Y. A retrospective evaluation of benign prostatic hyperplasia treatment by transurethral vaporization using a $1470 \mathrm{~nm}$ laser. Photomed Laser Surg 2013;31:626-9.

13. AL-Nashi AP, Raheem AA, Lateef Gr. Isolate and diagnose the bacteria present in the hospital in the city of Diwaniyah and the statement of the mechanisms to control the use of antibiotics and antiseptics. Al-Qadisiyah J Pure Sci 2013;18:11-20.

14. Hamann MF, Naumann CM, Seif C, van der Horst C, Jünemann KP, Braun PM. Functional outcome following photoselectivevaporisation of the prostate (PVP): Urodynamic findings within 12 months follow-up. Eur Urol 2008;54:902-7.

15. Gilling PJ, Kennett KM, Fraundorfer MR. Holmium laser enucleation of the prostate for glands larger than $100 \mathrm{~g}$ : An endourologic alternative to open prostatectomy. J Endourol 2000;14:529-31.

16. Reich O. Editorial comment on: Functional outcome following photoselectivevaporisation of the prostate (PVP): Urodynamic findings within 12 months followup. Eur Urol 2008;54:908.

17. Shamran AR, Shaker ZH, Al-Awsi GR, Khamis AS, Tolaifeh ZA, Jameel Z I. Rapd-PCR is a good DNA fingerprinting technique to detect phylogenetic relationships among Staphylococcus aureus isolated from different sources in Hilla city, Iraq. Biochem Cell Arch 2018;18:1157-61.

18. Erol A, Cam K, Tekin A, Memik O, Coban S, Ozer Y. High power diode laser vaporization of the prostate: Preliminary results for benign prostatic hyperplasia. J Urol 2009;182:1078-82.

19. Hendrika Y, Reveny J, Sumaiyah S. Formulation and in vitro evaluation of gastroretentive floating beads of amoxicillin using pectin from banana peel (Musa balbisiana AB). Asian J Pharm Clin Res 2018;11:72-7.

20. Gowda S, Patil N, Kotian R. Hypertrophic cardiomyopathy with partial anomalous pulmonary venous connection and atrial septal defect: A rare presentation. Asian J Pharm Clin Res 2017;10:5-7.

21. Thadiboina M, Adithya S, Vadivel K. Drug utilisation review in postoperativepatients in obstetrics-gynaecology and surgical gastroenterology departments-a retrospectve study. Int J Pharm Pharm Sci 2018;10:11-5.

22. Mandpe P, Prabhakar B. Pathophysiology, mechanism and management of overactive bladder syndrome - A review. Int J Pharm Pharm Sci 2018;10:1-3 